thoir attention directed to the vital tasks connected with the social relations of science. Increased knowledge is needed in this field in order to weigh the value of different resoarch projects in the industrial countries and to build up a research apparatus in the developing countrios.

Social science invostigations of numorous aspects of 'rosearch' were started by English scientists in the 'thirties.
That these studies did not lead furthor was due largely to idoologieal disagrooment on the planning of science. To-day tho chances of success are better, but occasional reflexions on the vital importance of this field will not suffice. What is needed is much hard work by a great many competent persons over a prolonged period.

Sverker Gustavsson

\title{
ADVANCEMENT OF SCIENTIFIC EDUCATION IN SCHOOLS
}

\begin{abstract}
HEE final report of the Industrial Fund for tho Advancement of Scientific Fducation in Schools* is a brief record of a creditable opisode in the history of education in the United Kingdom and Northern Ireland, which has now come to an end. The Fund was established in 1955, mainly on the initiative of Lord Weeks, Sir Alan Wilson, Mr. J. Oriol and Mr. G. Courtauld. Its object was to give a boost to the supply of scientists and technologists. Contributions were received from 141 industrial concerns, and the total sum accumulated amounted to $£ 3,211,035$. From this sum grants amounting to $£ 2,640,500$ were made to 210 schools for the renovation and extension of buildings for science teaching, and 129 schools received assistance for obtaining upparatus. Among the smallor items, a sum was set aside for the publication of a book on the planning and equipment of laboratories, based on exporience acquired through the Fund; seven schools were given an engine test bed; and a special grant was allotted to Malvern College where, through aid provided by the Nuffield Foundation, new approaches are being made to the teaching of physics. Assistance was limited to independent and direct-grant schools for boys and girls, since maintained schools are the concern of the Government and Local Fducation Authorities; throughout the duration of the schome interest was concentrated on the 'exact' sciences, so that the teaching of biology benefited only indirectly.

In attempting to assess the success of the scheme it is not possible to arrive at precise conclusions because of the interplay of a varioty of factors. But one point not mentioned in the report is that the Fund must have been a great boon to the schools concerned in a post-war period of economio and porsonal austerities. Since 1955, the
\end{abstract}

- Report on the Industrial Fund for the Advancement of Scientinc Education in Schools. Pp. iii +36 . (Barbary, Maresfleld Park, Uckfleld: Sir Qraham Savage (Chief Assessor), 1964.) number of sixth-form members spocializing in mathematics and science has greatly expandod; it is now common practice for all boys to be taught some science before taking the Ordinary Level Exarnination of the General Certificate of Education, and many schools have organizod courses in scienco for arts specialists.

Only in the fourteen girls' schools which recoived grants have the results been disappointing. In them, staffing may have been a more difficult problem than lack of facilities; and apart from modicine and its associated servioes, girls and headmistresses alike do not look favourably on careers in science. Yet the fow girls who do take science at the Advanced Lovel of the General Certificate of Education do well in it and particularly well in biology.

Other questions are posed by the report. In some boys; schools the "express line" of preparation for the Ordinary Level Examination of the Goneral Cortificate of Education is producing an increasing number of boys spending a third yoar in the sixth form, which would seom to bo undesirable. Again, in rocent yoars urts specialists have been increasing about twice as fast as specialists in science; in fact, recently in the larger public schools the number of science specialists has tended to fall, suggesting that science is not appealing to some of the most able boys. That in turn may have some relation to the limited amount of scionco boing taught in preparatory schools, although in them there has been somo improvement over the past few years. Finslly, to the oredit of the Fund it can be said that the standard of accommodation for teaching science which it provided was higher than that envisaged by the Ministry of Education in its Building Bulletin No. 2A, 1954, while the standard of equipment in maintained schools continues to give grounds for concern in relation to the place of science in the modern world and the extent to which teachers become discouraged and frustrated by present conditions.

\section{ANISOTROPY OF FRICTION IN CRYSTALS}

\author{
By Dr. F. P. BOWDEN, C.B.E., F.R.S., Dr. C. A. BROOKES and A. E. HANWELL \\ Laboratory for the Physics and Chemistry of Solids, Cavendish Laboratory, University of Cambridge
}

$\mathrm{E}^{\prime}$ ARLIFR oxperiments in this laboratory have shown that the friction of diamond is dopendent on the crystallogrsphic direction of sliding ${ }^{1}$ ' . With a diarnond slider (of constant orientation) sliding at low spoed on the cube face of a polished diamond the coefficient of friction was $\mu=0.15$ when sliding in the [100] direction (parallol to the oube edgo) and $\mu=0.05$ in tho [110] direction (diagonal to the cube edge). Frictional anisotropy has also been observed on other crystals, for oxample, sapphiro and copper ${ }^{5}$.

Magnesium oxide. Wo have rocently examined tho frictional behaviour of single crystals of magnesium oxide. This is a convenient orystal since it cleaves readily on the (001) faco to give a flat surface and the techniquos for oxamination by chemical polishing, dislocation etching and olectron microscopy are well established. With a hemispherical slider moving at low spoed $(0.1 \mathrm{~mm} / \mathrm{sec})$ on a oleaved face in air under a load of $30 \mathrm{~g}$ the coefficient of friction was $\mu \simeq 0.2$ and appreciable plastic deformation occurred beneath the surface of the crystal. This is illustrated by Fig. 1. There are two major foatures revealed by this photo-micrograph. First, the processes of fracture which govern the formation of woar dobris occur both on and boneath the surface. Secondly, slip has taken place prodominantly on those (110) planes which intersect the deformed surface at $45^{\circ}$, although somo slip on those (110) planes at $90^{\circ}$ to that surface is revealed. The maximum shear stross, under these conditions, is at a point below the surface and it is from this rogion that the dislocation loops originate and multiply. Similar deformation has been obsorved under conditions of rolling friction ${ }^{6}$.

$A$ crystal of magnosium oxide exhibits a marked anisotropy in its mochanicel propertios. Mossurements of hardness, for example, show that this is vory dopondent 